\title{
Cosmeceutical Activity of Broccoli (Brassica oleracea var. italica Plenck) with Different Light Sources
}

\author{
Soo-Yeon Lee', Hye-Ji Jun', Ji-Young Yoon', Tae-Su Kim², So-i Park², Sung-Pyo Lee², Joo-Hoon \\ Park ${ }^{1}$ and Jin-Young Lee *
}

\author{
${ }^{1}$ Department of Herbal Cosmetic Science, Hoseo University, Chungnam 336-795, Korea \\ ${ }^{2}$ Misuba RTech Co, Ltd, Chungnam, 336-795, Korea
}

Received November 4, 2011 /Revised February 14, 2012 / Accepted February 14, 2012

\begin{abstract}
The purpose of this study was to research the cosmeceutical activity of $70 \%$ ethanol extracts when Brassica deracea var. italica Plenck (BO) was dried under red lighting (RLD), blue lighting (BLD), red+blue lighting (RBLD), or white lighting (WLD). The electron-donating abilities of 70\% ethanol extracts from drying BO under RLD, BLD, RBLD, and WLD were $62.8 \%, 68.1 \%, 60.9 \%$, and $69.9 \%$, respectively, at a concentration of $500 \mathrm{ppm}$. The superoxide dismutase (SOD)-like activities of $70 \%$ ethanol extracts from drying BO under RLD, BLD, RBLD, and WLD were $39.2 \%, 47.2 \%, 19.6 \%$, and $21.6 \%$, respectively, at a concentration of $1,000 \mathrm{ppm}$. In terms of xanthine oxidase inhibition effects, the proportions of $70 \%$ ethanol extracts after drying BO under RLD, BLD, RBLD, and WLD were $45.1 \%, 56.2 \%, 38.8 \%$, and $53.3 \%$, respectively, at a concentration of $1,000 \mathrm{ppm}$. The tyrosinase inhibition effects of $70 \%$ ethanol extracts when BO was dried under RLD, BLD, RBLD, and WLD were $21.0 \%, 13.1 \%, 26.0 \%$, and $19.1 \%$, respectively, at a concentration of 1,000 ppm. The collagenase inhibition effect of $70 \%$ ethanol extracts when BO was dried under RLD, BLD, RBLD, and WLD were $47.4 \%, 20.8 \%, 54.6 \%$, and $37.2 \%$, respectively, at a concentration of $1,000 \mathrm{ppm}$. The astringent inhibition effects of $70 \%$ ethanol extracts when BO was dried under RLD, BLD, RBLD, and WLD were $21.5 \%, 39.6 \%, 40.0 \%$, and $51.6 \%$, respectively, at a concentration of 5,000 ppm. All of these findings suggest that BO extracts dried under RLD, BLD, RBLD, and WLD have great potential as a cosmeceutical ingredient with good biological activity.
\end{abstract}

Key words : Anti-oxidant, broccoli, cosmeceutical, different light source

\section{서 론}

최근 현대인들 사이에 생활환경, 식생활 패턴의 변화, 과도 한 스트레스 등으로 인해 암, 심장질환, 동맥경화, 고혈압 등과 같은 각종 성인병이 증가하고 있다. 이러한 질병의 여러 원인 들 중에 superoxide anion radical $\left(\mathrm{O}_{2}\right)$, hydroxy radical $(\mathrm{OH})$, singlet oxygen $\left({ }^{1} \mathrm{O}_{2}\right)$ 및 hydrogen peroxide $\left(\mathrm{H}_{2} \mathrm{O}_{2}\right)$ 등과 같은 활성산소가 주목되고 있다[15,32]. 그 중 Free radical은 인체 내의 산소유입으로 인해 만들어진 superoxide에서 과산화수 소가 생성되며, 이 과산화수소로부터 hydroxy radical과 singlet oxygen과 같은 활성산소가 만들어 진다[30]. Free radical 은 이러한 정상적인 대사과정에서의 생성뿐만 아니라 질병이 나 스트레스로 인해 과잉 생성되기도 하며 흡연, 공해, 세균감 염 등도 free radical의 생성을 증가시키는 원인이 된다. 이와 같은 free radical의 산화적 스트레스는 피부노화의 주요 원인 으로 작용하며, 이러한 피부 노화를 지연시키고 억제하기 위 해서는 free radical 생성을 억제 또는 제거할 수 있는 효율적인 방어망을 구축할 필요가 있다[18]. 또한 피부노화를 막기 위해

*Corresponding author

Tel : +82-41-540-9552, Fax : +82-41-540-9538

E-mail : jylee@hoseo.edu
의학적 효능을 강화한 소재들이 지속적으로 개발되면서 과학 과 의학을 접목시킨 뛰어난 효능의 기능성 소재들이 꿈의 실 현가능성을 더욱 높여주고 있다[21]. 이러한 천연소재의 사용 은 효능과 안정성 면에서 뛰어난 장점을 지니고 있기 때문에 천연물분리 기술 등과 관련 응용기술의 발전으로 식물성 원료 뿐만 아니라 각종 천연물 자원을 이용한 기능성 소재 개발이 가능해지고 있다[21]. 우리들이 소비하는 농산물은 자연을 상 대로 하여 생산하는 농업의 특성상 자연환경에 의해 수확량과 품질에 영향을 받는다. 자연재해를 극복하기 위해 시설하우스 와 여러 농기계를 활용하여 농작물을 재배하고 있지만 지금 농촌의 현실은 농업인의 고령화와 인구 감소, 보호농업정책에 의한 농촌의 경쟁력 상실 등의 문제점으로 자연재해를 효과적 으로 극복할 여력이나 해결책이 없는 실정이다. 그래서 최근 계절이나 기온, 풍수해 등 자연환경에 구애 받지 않고 일정한 공간에서 농작물 생육에 필요한 여러 가지 기기를 설치하여 환경조건을 제어하면서 농작물을 공장에서 생산하는 방식으 로 식물을 재배하는 식물공장에 관심을 갖게 되었다[20]. 식물 공장(Plant factory)이란 통제된 일정한 시설 내에서 빛, 온도, 습도, 양액조성, 대기가스 농도 등의 재배환경조건을 인공적 으로 제어하여 계절이나 장소에 관계없이 농작물을 공산품처 럼 계획적으로 연속 생산하는 시스템적인 농업의 한 형태를 
말한다[26]. 식물공장에서 사용되는 광원으로는 LED가 추천 되고 있는데 이는 특정한 광파장을 조절할 수 있는 장점으로 기능성 성분의 함량을 증가시킬 수 있다고 한다[33,34].

브로콜리(Brassica oleracea var. italica Plenck)는 십자화과에 속하는 채소로 잎과 줄기는 모두 버려지고 작은 꽃봉오리가 다발로 이루어진 꽃만을 식용하며, 한 줄기에서 꽃이 4 5개 정도 맺히고, 잎은 10 15장 이상 나와 매우 무성하게 된다[23]. 브로콜리는 항산화물질로 알려진 ascorbic acid, $\beta$-carotene, rutin, selenium, glutathione, quercetin 등이 다량 함유 되어 있으며, 암세포증식억제 및 해독효소의 유도효과가 크다고 알 려져 많은 연구가 진행되고 있다[23,38]. 특히, 브로콜리에는 신체의 지연 치유력을 증강시켜 암 발생의 위험성을 줄여주는 물질인 sulforaphane (S-methylsulfinylbutyl isothiocyanate) 이 함유되어 있다고 알려져 있는데 [24,43], sulforaphane은 최 근 연구에서 발암물질로 전 처리한 생쥐의 유선에서 종양발생 을 억제하고[10], 전립선암의 예방에도 유효한 것으로 보고되 었으며[4], in vitro 실험에서 sulforaphane이 암 예방 효과뿐만 아니라 헬리코박터에 대한 강력한 살균효과가 있음이 보고되 었다[9]. 또한 광원의 종류를 달리한 브로콜리 새싹의 이화학 적 특성 연구에서 일반성분, 유리당 함량, 클로로필 함량, 유기 산 함량, 비타민 A, C, E 함량, 무기질 조성 등의 영양화학적 성분이 광원에 따라 식물체 내 영양화학적 성분에 큰 영향을 일으킨다는 보고도 있다[25]. 이러한 여러 가지 유익한 생리활 성 성분을 함유한 브로콜리는 기존의 자외선 차단제들과 달리 sulforaphane 성분이 함유되어 있어, 자외선으로 인한 피부손 상을 저해하고 세포 자체의 억제력을 향상시킨다는 보고도 있다[14]. 이에 본 연구에서는 식물공장시스템에서 브로콜리 종자를 발아하여 광원별로 재배한 브로콜리를 이용하여 다양 한 화장품약리활성을 in vitro 상에서 검증하고 화장품 소재로 활용하기 위한 기초자료를 제공하고자 한다.

\section{재료 및 방법}

\section{재료 추출}

본 실험에 사용된 브로콜리 새싹은 (주)미스바알텍의 식물 공장에서 $430 \mathrm{~nm}$ 내지 $460 \mathrm{~nm}$ 파장 범위의 LED 청색광원을 발아 2일(암조건), 4 일 동안 하루에 10시간씩 조사시켰으며, 적색광원은 $650 \mathrm{~nm}$ 내지 $680 \mathrm{~nm}$ 범위의 LED 광원, 적색+청 색 LED광원, 일반 LED광원을 사용하였다. 온도 범위는 21 2 $3^{\circ} \mathrm{C}$, 습도는 $45 \sim 60 \%$ 로 조절하여 브로콜리 새싹을 재배하였으 며, 수분이 많아 신선한 상태로 장기저장이 어려운 문제점이 있어 저온열풍건조기 $60^{\circ} \mathrm{C}$ 에서 24시간 동안 건조한 후 200 mesh로 분쇄하였다. 이렇게 분쇄한 브로콜리 새싹에 에탄올 을 10 배 가량 넣고 실온에서 24 시간 침지하여 3 회 반복하여 추출액을 얻었으며, 이 추출액을 여과지를 사용해 여과한 다 음 감압 농축기를 사용하여 농축하고 동결건조하여 본 실험의
시료로 사용하였다.

\section{실험 시약}

항산화 효과 측정에 사용된 시약인 1,1-diphenyl-2-picrylhydrazyl (DPPH), pyrogallol, xanthine oxidase와 미백 및 주름억제 효과 측정에 사용된 시약인 tyrosinase, collagenase 및 4-phenylazobenzyloxycarbonyl-Pro-Leu-Gly-Pro-D-Arg 등은 Sigma Chemical Co. (St. Louis, MO, USA)에서 구입하여 사용하였다.

\section{전자공여능 측정}

전자공여능(EDA: electron donating ability)은 Blois의 방법 [3]을 변형하여 측정하였다. 각 시료용액 $120 \mu 1$ 에 $0.2 \mathrm{mM}$ 의 1,1-diphenyl-2-picrylhydrazyl(DPPH) $60 \mu \mathrm{l}$ 넣고 15분간 실온 에서 방치한 다음 $517 \mathrm{~nm}$ 에서 흡광도를 측정하였다. 전자공여 능은 시료용액의 첨가 군과 무 첨가 군의 흡광도 감소율로 나타내었다.

$$
\text { 전자공여능 }(\%)=\left(1-\frac{\text { 시료첨가군의 흡광도 }}{\text { 무첨가군의 흡광도 }}\right) \times 100
$$

\section{Superoxide dismutase (SOD) 유사활성 측정}

SOD 유사활성은 Marklund의 방법[31]에 따라 측정하였다. 각 시료용액 $20 \mu \mathrm{l}$ 에 tris- $\mathrm{HCl}$ 완충용액 $(50 \mathrm{mM}$ tris- $\mathrm{HCl}$ buffer, $\mathrm{pH}$ 8.5) $130 \mu \mathrm{l}$ 와 $7.2 \mathrm{mM}$ pyrogallol $20 \mu 1$ 를 가하여 $37^{\circ} \mathrm{C}$ 에 서 10 분간 반응시킨 후 $420 \mathrm{~nm}$ 에서 흡광도를 측정하였다. $\mathrm{SOD}$ 유사활성은 시료용액의 첨가 군과 무 첨가 군의 흡광도 감소율로 나타내었다.

$$
\mathrm{SOD} \text { 유사활성능 }(\%)=\left(1-\frac{\text { 시료첨가군의 흡광도 }}{\text { 무첨가군의 흡광도 }}\right) \times 100
$$

\section{Xanthine oxidase 저해활성 측정}

Xanthine oxidase 저해활성은 Stirpe와 Corte의 방법[39]에 따라 측정하였다. 각 시료용액 $0.1 \mathrm{ml}$ 와 $0.1 \mathrm{M}$ potassium phosphate buffer (pH 7.5) $0.6 \mathrm{ml}$ 에 xanthine $(2 \mathrm{mM})$ 을 녹인 기질액 $0.2 \mathrm{ml}$ 를 첨가하고 xanthine oxidase $(0.2 \mathrm{U} / \mathrm{ml}) 0.1$ $\mathrm{ml}$ 를 가하여 $37^{\circ} \mathrm{C}$ 에서 15 분간 반응시킨 후 $1 \mathrm{~N} \mathrm{HCl} 1 \mathrm{ml}$ 를 가하여 반응을 종료시킨 다음, 반응액 중에 생성된 uric acid의 양을 $292 \mathrm{~nm}$ 에서 흡광도를 측정하였다. Xanthine oxidase 저 해활성은 시료용액의 첨가 군과 무 첨가 군의 흡광도 감소율 로 나타내었다.

$$
\text { 저해율 }(\%)=\left(1-\frac{\text { 시료첨가군의 uric acid 생성량 }}{\text { 무첨가군의 uric acid 생성량 }}\right) \times 100
$$

\section{Tyrosinase 저해활성 측정}

Tyrosinase 저해활성 측정은 Yagi 등[42]의 방법에 따라 측정하였다. $67 \mathrm{mM}$ sodium phosphate buffer $(\mathrm{pH}$ 6.8) 80 $\mu \mathrm{l}$ 에 $10 \mathrm{mM} \mathrm{L-DOPA}$ 를 녹인 기질액 $40 \mu \mathrm{l}$ 및 시료용액 40 
$\mu \mathrm{l}$ 의 혼합액에 mushroom tyrosinase $(200 \mathrm{U} / \mathrm{ml}) 40 \mu \mathrm{l}$ 을 첨 가하여 $37^{\circ} \mathrm{C}$ 에서 10 분간 반응시켜 반응액 중에 생성된 DOPA chrome을 $475 \mathrm{~nm}$ 에서 측정하였다. Tyrosinase 저해 활성은 시료용액의 첨가 군과 무 첨가 군의 흡광도 감소율로 나타내었다.

$$
\text { 저해율 }(\%)=\left(1-\frac{\text { 시료첨가군의 흡광도 }}{\text { 무첨가군의 흡광도 }}\right) \times 100
$$

\section{Collagenase 저해활성 측정}

Collagenase 저해활성 측정은 Wünsch 등[41]의 방법에 따 라 측정하였다. 즉 $0.1 \mathrm{M}$ tris- $\mathrm{HCl}$ buffer (pH 7.5)에 $4 \mathrm{mM}$ $\mathrm{CaCl}_{2}$ 를 첨가한 용액 $250 \mu \mathrm{l}$ 와 4-phenylazobenzyl-oxycarbonyl-Pro-Leu-Gly-Pro-D-Arg $(0.3 \mathrm{mg} / \mathrm{ml})$ 을 녹인 기질액 $125 \mu \mathrm{l}$ 및 시료용액 $50 \mu \mathrm{l}$ 의 혼합액에 collagenase $(0.2 \mathrm{mg} / \mathrm{ml})$ $75 \mu 1$ 를 첨가하여 실온에서 20 분간 방치한 후 $6 \%$ citric acid $250 \mu 1$ 을 넣어 반응을 정지 시킨 후, ethyl acetate $1.5 \mathrm{ml}$ 을 첨가하여 $320 \mathrm{~nm}$ 에서 흡광도를 측정하였다. Collagenase 저 해활성은 시료용액의 첨가 군과 무 첨가 군의 흡광도 감소율 로 나타내었다.

$$
\text { 저해율 }(\%)=\left(1-\frac{\text { 시료첨가군의 흡광도 }}{\text { 무첨가군의 흡광도 }}\right) \times 100
$$

\section{Astringent 활성 측정}

Astringent 활성 측정은 Lee 등[28]의 방법에 따라 측정하였 다. 피부 단백질과 유사한 혈액 단백질(hemoglobin)을 사용하 여, 원심분리 관 용기에 각각의 시료용액과 헤모글로빈 용액 을 $0.5 \mathrm{ml}$ 씩 1:1로 넣어서 진탕 혼합한 다음 $1,500 \mathrm{rpm}$ 에서 3 분간 원심분리 후 $576 \mathrm{~nm}$ 에서 흡광도를 측정하였다. Astringent 활성 측정은 시료용액의 첨가 군과 무 첨가 군의 흡광도 감소율로 나타내었다.

$$
\text { Astringent 활성능 }(\%)=\left(1-\frac{\text { 시료첨가군의 흡광도 }}{\text { 무첨가군의 흡광도 }}\right) \times 100
$$

\section{통계 처리}

모든 실험은 3 회 반복하여 실시하였고, 평균과 표준편차 계 산 후 그 결과를 비교하여 오차막대로 표시하였다.

\section{결과 및 고찰}

\section{전자공여능 확인}

전자공여능 측정에 사용된 1-1-diphenyl-2-picryl-hydrazyl (DPPH)는 짙은 자색을 띄는 비교적 안정한 free radical 로서 cystein, glutathion과 같은 황을 함유하는 아미노산과 ascorbic acid, BHA 등에 의해 환원되어 탈색되므로 다양한 천연 소재로부터 항산화 물질을 검색하는데 많이 이용되고 있다[22].

브로콜리의 광원별 특성에 따라 전자공여능을 측정한 결과 Fig. 1 과 같이 나타내었다. 적색광, 청색광, 적. 청색광, 형광등

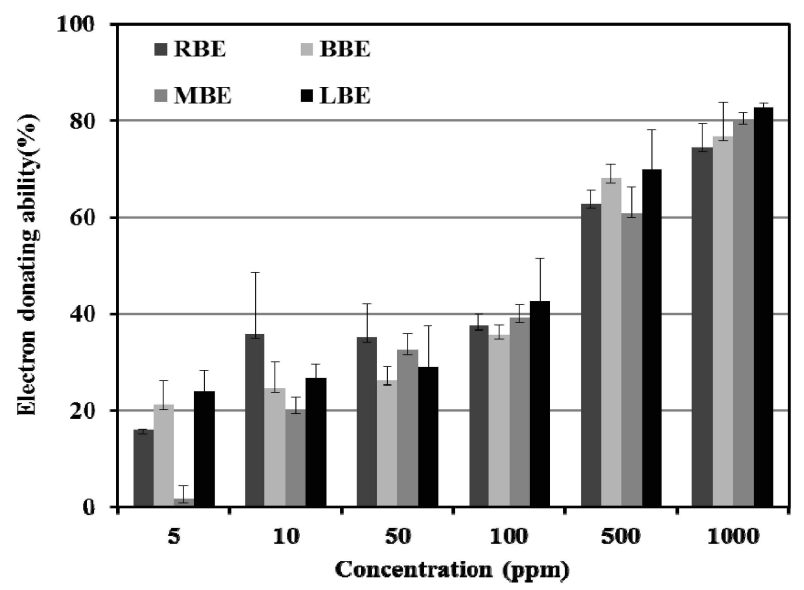

Fig. 1. Electron donating ability of Brassica oleracea var italica Plenck by different light source. $\square$ RBE: Brassica oleracea var italica Plenck in red light, BBE: Brassica oleracea var italica Plenck in blue light, —MBE: Brassica oleracea var italica Plenck in red and blue light, $\square$ LBE: Brassica oleracea var italica Plenck in fluorescent lamp, Result are means \pm S.D. of triplicate data.

브로콜리의 에탄올추출물은 $500 \mathrm{ppm}$ 에서 각각 $62.8 \%, 68.1 \%$, $60.9 \%, 69.9 \%$ 의 활성을 나타내었고, 이들 브로콜리의 전자공 여능은 형광등, 청색광, 적색광, 적·청색광 순으로 활성이 높 았으나, 광원별 활성의 차이는 크지 않았으며, 전반적으로 우 수한 활성을 나타내었다.

\section{$\mathrm{SOD}$ 유사활성능 검증}

Superoxide radical 소거활성능은 알칼리 상태에서 pyrogalloloㅢ 자동산화에 의한 발색을 이용한 측정방법으로 pyrogallolo은 수용액에서 자동산화가 빠르게 일어나는데 여기에 는 superoxide가 관여한다고 알려져 있다[8,31].

광원별 브로콜리 에탄올추출물의 SOD유사활성능을 측정 한 결과 Fig. 2 와 같이 나타내었다. 적색광, 청색광, 적-청색광, 형광등 브로콜리의 에탄올추출물은 $1,000 \mathrm{ppm}$ 에서 각각 $39.2 \%, 47.2 \%, 19.6 \%, 21.6 \%$ 의 유사활성능을 나타내어 청색광 에서 가장 높은 활성을 확인할 수 있었다. 이는 Jeong[19]의 연구에서 산마늘(Allium victorialis L.)의 비 발효 추출물과 발 효 추출물에서 각각 $15.2 \%, 15.0 \%$ 의 활성을 나타낸 결과와 비 교해 보았을 때 청색광 및 적색광 브로콜리의 에탄올 추출물 에서 더 높은 SOD 유사활성능을 확인할 수 있었다. 특히 SOD 유사활성능에서는 광원별 활성의 차이가 2 배 이상 나타남을 확인할 수 있었는데, 이러한 광원을 효과적으로 이용한다면 추출물의 활성을 높일 수 있는 좋은 전처리 과정이 될 것으로 사료된다.

Xanthine oxidase 저해활성 확인

광원별 브로콜리 에탄올추출물의 xanthine oxidase 저해활 


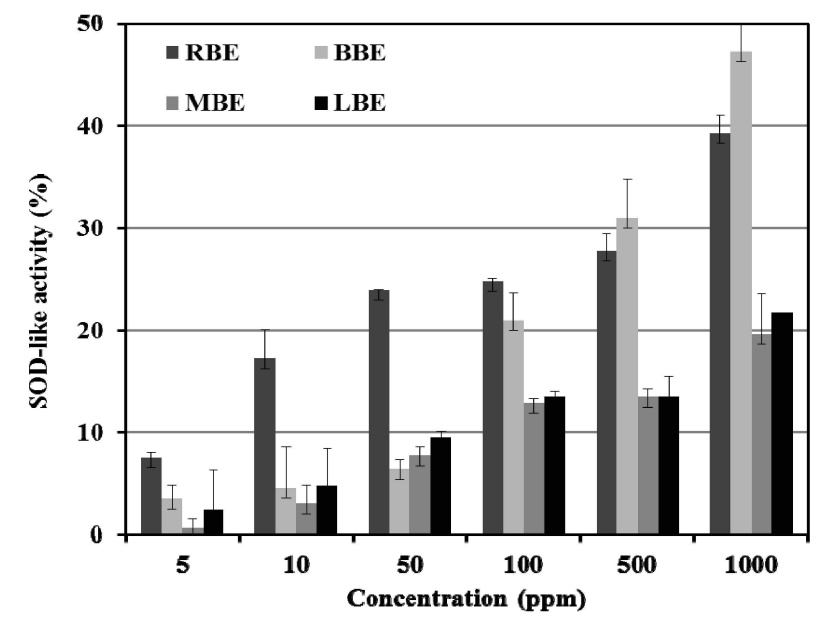

Fig. 2. SOD-like activity of Brassica oleracea var italica Plenck by different light source. $\square$ RBE: Brassica oleracea var italica Plenck in red light, BBE: Brassica oleracea var italica Plenck in blue light, MBE: Brassica oleracea var italica Plenck in red and blue light, LBE: Brassica oleracea var italica Plenck in fluorescent lamp, Result are means \pm S.D. of triplicate data.

성을 측정한 결과 Fig. 3 과 같이 나타내었다. 적색광, 청색광, 적 · 청색광, 형광등 브로콜리의 에탄올추출물은 $1,000 \mathrm{ppm}$ 에 서 각각 $45.1 \%, 56.2 \%, 38.8 \%, 53.3 \%$ 의 xanthine oxidase 저해 활성을 나타내어 적.청색광, 적색광, 형광등, 청색광의 순서로 저해활성이 높아지는 것을 확인하였고, 청색광과 형광등의 브 로콜리 에탄올추출물이 가장 높은 저해활성을 나타내었다. 특 히 청색광은 $10 \mathrm{ppm}$ 에서부터 $24.8 \%$ 이상의 저해활성을 나타 내었다. 이는 An 등[1]의 연구에서 황련(Coptidis Rhizoma) 추 출물의 에탄올추출물과 열수추출물 $1,000 \mathrm{ppm}$ 에서 각각 $18.8 \%, 6.9 \%$ 의 활성을 나타낸 결과와 비교해보았을 때 광원별 브로콜리의 에탄올 추출물의 저해활성이 우수함을 확인할 수 있었다. 항산화 효과 실험인 DPPH, SOD, xanthine oxidase 저해활성 측정에서는 청색광원의 브로콜리 추출물의 활성이 다른 광원에 비해 우수함을 확인할 수 있어, 항노화 화장품 개발 시 청색광원을 이용하면 좀 더 활성이 높은 화장품을 개발할 수 있을 것으로 사료된다.

\section{Tyrosinase 저해활성 확인}

Tyrosinase는 tyrosin으로부터 3,4-dihydroxy-L-phenylalanin (DOPA)과 DOPA-quinone을 거쳐 최종적으로 흑갈색 의 melanin색소 생성에 관여하는 효소[13]로 자외선에 의하여 melanocyte의 유사분열이 일어나고 이어서 melanocyte가 활 성화 된다. 활성화 된 melanocyte에서는 tyrosinase 합성이 촉진되고 melanin의 생성이 항지되어 이를 표피 밖으로 운반 배출하게 되어 기미, 주근깨와 같은 색소 침착이 일어나게 된 다. 그러므로 tyrosinase 활성 억제제는 피부 내에서의 mela-

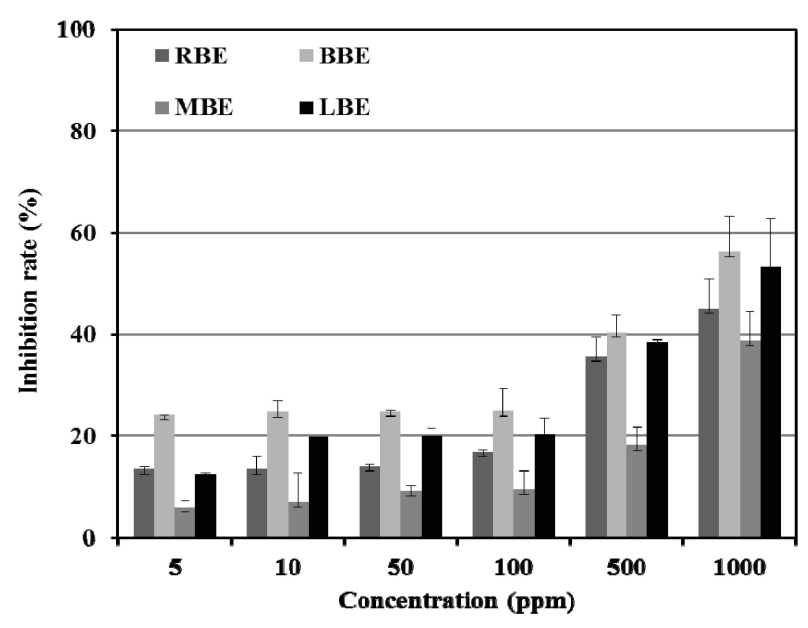

Fig. 3. Inhibition rate of Brassica oleracea var italica Plenck by different light source on xanthine oxidase. $\square$ RBE: Brassica oleracea var italica Plenck in red light, BBE: Brassica oleracea var italica Plenck in blue light, $1 \mathrm{MBE}$ : Brassica oleracea var italica Plenck in red and blue light, LBE: Brassica oleracea var italica Plenck in fluorescent lamp, Result are means \pm S.D. of triplicate data.

nin polymer 합성을 효과적으로 저해할 수 있어 피부 미백제 의 개발에 있어서 tyrosinase 활성억제 실험은 유용한 평가법 으로 인정되고 있다[16,17].

광원별 브로콜리 에탄올추출물의 tyrosinase저해활성을 측 정한 결과 Fig. 4 와 같이 나타내었다. 적색광, 청색광, 적.청색 광, 형광등 브로콜리의 에탄올추출물은 $1,000 \mathrm{ppm}$ 에서 각각 $21.0 \%, 13.1 \%, 26.0 \%, 19.1 \%$ 의 저해활성을 나타내어 적.청색 광에서 건조시킨 브로콜리에서 가장 높은 결과를 확인하였다. 이는 Choi의 연구[5]에서 황백(Phellodendron amurense R.)의 에탄올추출물과 열수추출물이 $1,000 \mathrm{ppm}$ 에서 모두 $10 \%$ 미만 의 미비한 활성을 나타낸 결과와 비교했을 때, 적색광과 적·청 색광의 브로콜리 에탄올추출물의 tyrosinase 저해활성이 비교 적 높았음을 확인할 수 있었으나, 다른 결과와 비교하여 뚜렷 한 활성의 변화는 없었다.

\section{Collagenase 저해활성 확인}

세포 외 기질(extracellular matrix)의 주요 구성 성분인 collagen은 피부의 섬유아 세포에서 생성되는 주요 기질 단백질 이다. Collagen의 주된 기능으로는 피부의 기계적 견고성, 결 합조직의 저항력과 조직의 결합력, 세포 접착의 지탱, 세포 분할과 분화의 유도 등이 알려져 있다[37]. 이러한 collagen은 연령 및 자외선 조사에 의한 광노화에 의해 감소하며, 이는 피부의 주름 형성과 밀접한 연관이 있다고 알려져 있다 $[7,11,40]$. 또한 collagen은 트립신 등의 단백질 분해효소의 작 용을 받지 않으나, collagenase에 의해 분해된다는 보고가 있 어[6,12], 브로콜리를 이용하여 collagenase 저해활성을 측정 


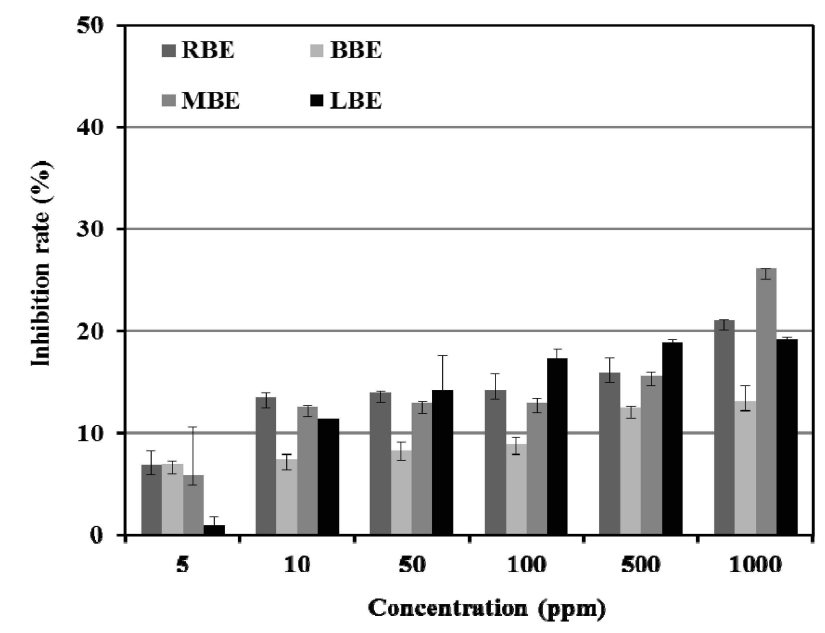

Fig. 4. Inhibition rate of Brassica oleracea var italica Plenck by different light source on tyrosinase. $\square$ RBE: Brassica oleracea var italica Plenck in red light, BBE: Brassica oleracea var italica Plenck in blue light, $\square$ MBE: Brassica deracea var italica Plenck in red and blue light, DLBE: Brassica oleracea var italica Plenck in fluorescent lamp, Result are means \pm S.D. of triplicate data.

하였다.

광원별 브로콜리의 에탄올추출물의 collagenase 저해활성 을 측정한 결과 Fig. 5 와 같이 나타내었다. 적색광, 청색광, 적. 청색광, 형광등 브로콜리의 에탄올추출물은 $1,000 \mathrm{ppm}$ 에서 각각 $47.4 \%, 20.8 \%, 54.6 \%, 37.2 \%$ 의 저해활성을 나타내어 청색 광, 형광등, 적색광, 적·청색광의 순서로 저해활성이 높았음을 확인하였다. 이는 Lee 등[29]의 연구에서 유백피(UImus macrocarpa Hance) 추출물의 collagenase 저해활성 측정 결과 $27.6 \%$ 를 나타내었으며 Barrantes 등[2]의 연구에서 알로에(Aloe barbadensis vera) 추출물이 $37.1 \%$ 를 나타낸 결과와 비교하였을 때 청색광 브로콜리 에탄올추출물을 제외한 나머지 광원별 추출물의 collagenase 저해활성이 유의성 있는 결과를 나타냄 을 확인할 수 있었다. 특히 적색광이 포함된 브로콜리의 collagenase 저해활성이 우수한 것으로 나타났는데, 이는 Kim등 [25]의 브로콜리의 이화학적 특성 연구에서 적색광원에서 일 반성분의 함량이 대부분 높게 나타난 결과와 관련이 있는 것 으로 판단된다.

\section{Astringent 활성 확인}

피부 단백질은 고분자 flavonoid인 polyphenol과 결합하여 가교결합을 형성하고 피부가 수축되어 수렴작용을 하게 된다 [35]. 본 실험에서는 hemoglobin의 단백질이 추출물과 결합하 는 정도에 따라 수렴효과 정도를 판단하였다. 이러한 수렴 작 용에는 외용 혹은 내용에 의해서 피부와 점막의 표면에 난용 성이 피막을 형성하고 그 결과 국소를 보호하거나, 혹은 조직 을 조밀하게 하여 세포막의 투과성을 감소시키는 효과가 있다

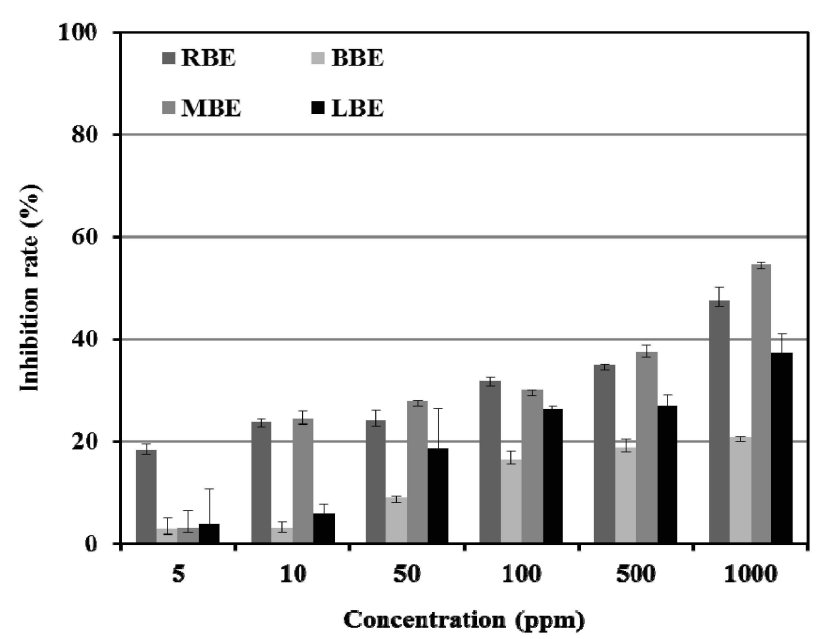

Fig. 5. Inhibition rate of Brassica oleracea var italica Plenck by different light source on collagenase. $\square$ RBE: Brassica oleracea var italica Plenck in red light, $\quad$ BBE: Brassica oleracea var italica Plenck in blue light, $\square \mathrm{MBE}$ : Brassica oleracea var italica Plenck in red and blue light, $\square$ LBE: Brassica oleracea var italica Plenck in fluorescent lamp, Result are means \pm S.D. of triplicate data.

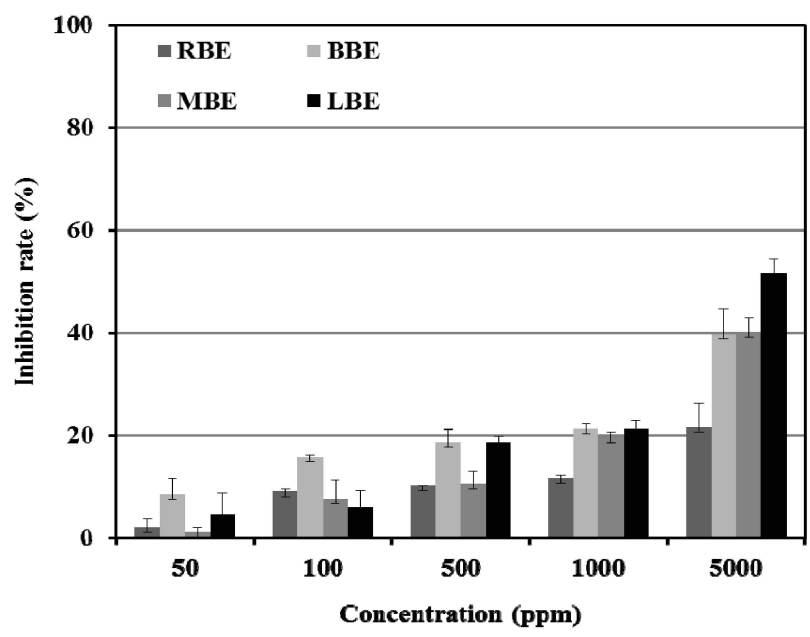

Fig. 6. Comparison of astringent activity on Brassica oleracea var italica Plenck by different light source. $\square$ RBE: Brassica oleracea var italica Plenck in red light, $\mathrm{BBE}$ : Brassica oleracea var italica Plenck in blue light, MBE: Brassica oleracea var italica Plenck in red and blue light, $\square$ LBE: Brassica oleracea var italica Plenck in fluorescent lamp, Result are means \pm S.D. of triplicate data.

고 보인다[36].

광원별 브로콜리 에탄올추출물의 수렴효과 측정인 astringent 활성 측정 결과 Fig. 6과 같이 나타내었다. 적색광, 청색광, 적.청색광, 형광등 브로콜리의 에탄올추출물은 5,000 $\mathrm{ppm}$ 에서 각각 $21.5 \%, 39.6 \%, 40.0 \%, 51.6 \%$ 의 활성을 나타내어 형광등, 적.청색광, 청색광, 적색광의 순서로 활성이 높았음을 
확인할 수 있었다. 이는 Lee 등[27]의 함초(Salicornia herbacea L.) 추출물의 에탄올추출물과 열수추출물은 각각 $16.7 \%$, $28.0 \%$ 의 활성을 나타낸 결과와 비교하였을 때, 광원별 브로콜 리의 에탄올추출물의 활성이 상대적으로 높은 것을 확인할 수 있었다. 앞의 결과들과 다르게 수렴효과에서는 형광등 브 로콜리 추출물의 활성이 높게 나타났는데, 이는 Kim 등[25]의 브로콜리 새싹의 이화학적 특성 연구에서 형광등 브로콜리의 조단백질 함량이 가장 높게 나타난 결과를 볼 때, 브로콜리 성분과 hemoglobin의 단백질과 결합하여 astringent 활성에 영향을 준 것으로 판단된다.

\section{감사의 글}

본 연구는 보건복지부 보건의료연구개발사업의 지원에 의 하여 이루어진 것임. (과제고유번호: A103017)

\section{References}

1. An, B. J., J. T. Lee, C. E. Lee, J. H. Kim, J. H. Son, J. H. Kwak, J. Y. Lee, T. S. Park, H. J. Bae, M. J. Jang, and C. H. Jo. 2005. A study on physiological activities of Coptidis Rhizoma and application for cosmetic ingredients. Korean J. Herbology 20, 83-92.

2. Barrantes, E. and M. Guinea. 2003. Inhibition of collagenase and metalloproteinase by anions and aloe gel. J. Life Sci. 72, 843-850.

3. Blois, M. S. 1958. Antioxidant determination by the use of a stable free radical. Nature 26, 1199-1200.

4. Brooks, J. D., V. G. Paton, and G. Vidanes. 2001. Potent induction of phase 2 enzymes in human prostate cells by sulforaphane. Cancer Epidemiol. Biomarkers prev. 10, 949-954.

5. Choi, I. S. 2009. Verification of effect with skin phamacological material and cosmetic application from medicinal plant. M. D. Thesis, Daegu Haany University, Gyeongbuk, Korea.

6. Demina, N. S. and S. V. Lysenko. 1996. Collagenolytic enzymes synthesized by microorganisms. Mikrobiologiia 65, 293-304.

7. El-Domyati, M., S. Attia, F. Saleh, D. Brown, D. E. Birk, F. Gasparro, H. Ahmad, and J. Uitto. 2002. Intrinsic aging vs. photoaging: a comparative histopathological, immunohistochemical, and ultrastructural study of skin. Exp. Dermatol. 11, 398-405.

8. Eugene, F., Jr. Roth, and S. G. Harriet. 1983. The pyrogallol assay for superoxide dismutase absence in glutathione artifact. Anal. Biochem 137, 50-53.

9. Fahey, J. W., X. Haristoy, P. M. Dolan, T. W. Kensler, I. Scholtus, K. K. Stephenson, P. Talaly, and A. Lozniewski. 2002. Sulforaphane inhibits extracellular, intracellular, and antibiotic-resistant strains of helicobacter pylori and pre-vents benzo[a]pyrene-induced stomach tumors. Proc. Natl. Acad Sci. 99, 7610-7615.
10. Gerhauser, C., M. You, J. Liu, R. M. Moriarty, M. Hawthorne, R. G. Mehta, R. C. Moon, and J. M. Pezzuto. 1997. Cancer chemopreventive potential of sulforamate, anovel analogue of sulforaphane that induces phase 2 drug-metabolizing enzymes. Cancer Res. 57, 272-278.

11. Giacomoni, P. U. and G. Rein. 2001. Factors of skin ageing share common mechanisms. Biogerontology 2, 219-229.

12. Grant, N. H. and H. E. Alburn. 1959. Studies on the collagenases of clostridium histolyticum. Arch Biochem Biophys. 82, 245-255.

13. Han, H. S., J. H. Park, H. J. Choi, J. H. Son, Y. H. Kim, S. Kim, and C. Choi. 2004. Biochemical analysis and physiological activity of perilla leaves. Korean J. Food Culture 19, 94-105.

14. Hwang, Y. H. 2010. Studies on nutritive function of Broccoli for skin health. M. D. Thesis, Sunchon National University, Jeonnam, Korea.

15. Imlay, J. A. and S. Linn. 1988. DNA damage and oxygen radical toxicity. Science 240, 1302-1309.

16. Imokawa, G. and Y. Mishima. 1980. Isolation and characterization of tyrosinase inhibitors and their differential action on melanogenic subcellular compartment in amelanotic and melanomas. Br. Japan Dermatol. 103, 625-633.

17. Imokawa, G. and Y. Mishima. 1981. Biochemical characterization of tyrosinase inhibitors using tyrosinase binding affinity chromatography. Br. Japan Dermatol. 104, 531-539.

18. Jang, J. A. 2001. Patent for anti-aging cosmetics. Health Industry Technology Trends 89-96.

19. Jeong, S. M. 2010. A study on the biological activity of fermented Allium victorialis L. extract. M. D. Thesis, Joongbu University, Chungnam, Korea.

20. Kim, J. W. 2010. Trend and direction for plant factory system. J. plant Biotechnol. 37, 442-455.

21. Kim, J. Y., Y. H. Lee, J. Y. Kim, and B. K. Roh. 2005. Study of antioxidation action of Lenonuri herba extract. J. Soc. Cosmet. Scientists Korea 31, 189-196.

22. Kim, M. J., I. J. Kim, S. Y. Nam, C. H. Lee, T. Yun, and B. H. Song. 2006. Effects of drying methods on content of active components, antioxidant activity and color values of Saururus chinensis Bail. Korean J. Medicinal Crop. Sci. 14, 8-13.

23. Kim, M. R., J. H. Kim, D. S. Wi, J. H. Na, and D. E. Sok. 1999. Volatile sulfur compounds, proximate components, minerals, vitamin $C$ content and sensory characteristics of the juices of kale and broccoli leaves. J. Korean Soc. Food Sci. Nutr. 28, 1201-1207.

24. Kim, M. R., K. J. Lee, J. H. Kim, and D. E. Sok. 1997. Determination of sulforaphane in cruciferous vegetable by SIM. Korean J. Food Sci. Technol. 29, 882-887.

25. Kim, T. S., S. P. Lee, S. I. Park, J. Y. Lee, S. Y. Lee, and H. J. Jun. 2011. Physico-chemical properties of Broccoli sprouts cultivated in a plant factory system with different lighting conditions. J. Korean Soc. Food Sci. Nutr. 40, 1757-1763.

26. Kozai, T. 2007. Propagation, grafting and transplant production in closed systems with artificial lighting for commercialization in Japan. Propagation of Ornamental Plants 7, 
145-149.

27. Lee, J. T. and B. J. An. 2002. Detection of physical activity of Salicornia herbacea. Kor. J. Herbology 17, 61-69.

28. Lee, J. T., Y. S. Jeong, and B. J. An. 2002. Physiological activity of Salicornia herbacea and its application for cosmetic materials. Kor. J. Herbology 17, 51-60.

29. Lee, T. W., S. N. Kim, U. K. Jee, and S. J. Hwang. 2004. Anti-wrinkle effect of pressure sensitive adhesive hydrogel patches containing Ulmi cortex extract. J. Kor. Pharm Sci. 34, 193-199.

30. Lim, H. J. 2004. Antioxidative compounds of Euryale ferox Salisb. M. D. Thesis, Chung-Ang University, Seoul, Korea.

31. Marklund, S. and G. Marklund. 1974. Involvement of the superoxide anion radical in the autoxidation of pyrogallol and a convenient assay for superoxide dismutase. Eur. J. Biochem 47, 469-474.

32. McCord, J. M. 1987. Oxygen derived radicals: A link between repercussion injury and inflammation. Fed Proc. 46, 2402-2406.

33. Nishimura, T., S. M. A. Zobayed, T. Kozai, and E. Goto. 2006. Effect of light quality of blue and red fluorescent lamps on growth of St. John's Wort (Hypericumper foratum L.). J. SHITA. 18, 225-229.

34. Nozue, H., A. Shimada, Y. Taniguchi, and M. Nozue. 2010. Improving the productivity of plants using an LED light equipped with a control module. J. SHITA. 22, 81-87.

35. Okuda, K. 1986. Astringent effects of plants component. Fragrance J. 6, 270-274.
36. Park, K. S. 2010. The study of cosmeceutical activities from Coffee Beans and application of MLV liposomes on advanced formulation. M. D. Thesis, Daegu Hanny University, Gyeongbuk, Korea.

37. Perlish, J. S., G. Lemlich, and R. Fleischmajer. 1998. Identification of collagen fibrils in scleroderma skin. J. Invest. Dermatol. 90, 48-54.

38. Sok, D. E., J. H. Kim, and M. R. Kim. 2003. Isolation and identification of bioactive organossulfur phytochemicals from solvent extract of broccoli. J. Korean Soc. Food Sci. Nutr. $32,315-319$.

39. Stirpe, F. and E. Della Corte. 1969. The regulation of rat liver xanthine oxidase. Conversion in vitro of the enzyme activity from dehydrogenase (type D) to oxidase (type O). J. Biol. Chem 244, 3855-3863.

40. Wlaschek, M., I. Tantcheva-Poor, L. Naderi, W. Ma, L. A. Schneider, Z. Razi-Wolf, J. Schuller, and K. ScharffetterKochanek. 2001. Solar UV irradiation and dermal photoaging. J. Photochem Photobiol. B. 63, 41-51.

41. Wúnsch, E. and H. G. Heindrich. 1963. Zur quantitativen bestimmung der collagenase. Hoppe-Seyler's. Physiol. Chem 333, 149-151.

42. Yagi, A., T. Kanbara, and N. Morinobu. 1986. The effect of tyrosinase inhibition for aloe. Planta Medica. 3981, 517-519.

43. Zhang, Y., P. Talalay, C. G. Cho, and G. H. Posner. 1992. A major inducer of anticarcinogenic protective enzymes from broccoli: isolation and elucidation of structure. Proc. Natl. Acad Sci. USA 89, 2399-2403.

\section{초록 : 광원별 브로콜리 추출물의 화장품약리활성 검증}

이수연 ${ }^{1} \cdot$ 전혜지 ${ }^{1} \cdot$ 윤지영 ${ }^{1}$ 김태수 ${ }^{2} \cdot$ 박소이 $^{2} \cdot$ 이성표 ${ }^{2} \cdot$ 박주훈 $^{1} \cdot$ 이진영 ${ }^{1} \star$

(호서대학교 한방화장품과학과, ${ }^{2}$ (주)미스바알텍)

본 연구에서는 십자화과에 속하는 식물인 브로콜리를 적색광, 청색광, 적·청색광, 형광등을 이용해 건조시킨 광원별 브로콜리 에탄올추출물의 항산화, 미백 및 주름 개선 효과 등의 화장품약리활성을 검증하였다. 항산화 활성을 검증하기 위해 전자공여능, SOD 유사활성능, xanthine oxidase 저해활성능을 측정한 결과, 전자 공여능에 서는 형광등, 청색광, 적색광, 적·청색광 브로콜리의 에탄올추출물의 순서로 높았고, SOD 유사활성능에서는 청색 광이, xanthine oxidase 저해활성능에서는 청색광과 형광등의 브로콜리 에탄올추출물의 활성이 가장 높았다. 미 백 효과를 검증하기 위해 tyrosinase 저해활성능을 측정한 결과, 적.청색광 브로콜리의 에탄올추출물이 가장 높 은 활성을 나타내었고, 주름 개선 효과를 검증하기 위해 collagenase 저해활성능을 측정한 결과 청색광, 형광등, 적색광, 적·청색광 브로콜리 에탄올추출물 순으로 높은 활성을 나타내었다. 수렴 효과를 검증하기 위해 astringent 활성을 측정한 결과 형광등 브로콜리의 에탄올추출물이 가장 높은 활성을 나타내었음을 확인하였다. 따 라서 적색광, 청색광, 적·청색광, 형광등을 이용해 건조시킨 광원별 브로콜리 에탄올 추출물의 기능성 소재의 가 능성을 확인하였다. 